\title{
Digital Game Addiction and Lifestyle Behaviors in Turkish Adolescents
}

\author{
Zahide Aksoy ${ }^{1}$, Saime Erol ${ }^{2}$ \\ ${ }^{1}$ Istanbul Sureyyapasa Chest Diseases And Thoracic Surgery Training And Research Hospital \\ ${ }^{2}$ Marmara University, Department of Public Health Nursing, Istanbul/Turkey \\ Correspondence Author: Zahide Aksoy \\ E-mail: aksoyzahide@outlook.com
}

Received: $24.02 .2021 \quad$ Accepted: 26.05 .2021

\begin{abstract}
Objective: Digital game addiction is a concern that threatens public health around the world, especially in adolescents. This study was conducted to determine the relationship between digital game addiction and lifestyle behaviors in adolescents.

Methods: The research was carried out in from three high schools offering different types of education in Maltepe district between March and April 2017. Data were collected by using the Introductory Information Form, Game Addiction Scale for Adolescents and Adolescent Lifestyle Profile Scale. Data were evaluated in computer environment. Descriptive data were shown with numbers, percentages and means. The relationship between game addiction and independent variables was evaluated by chi-square test, Mann-Whitney U test, Pearson Correlation Analysis and Logistic Regression Analysis.

Results: $22.4 \%$ of adolescents were determined to be addicted to digital games. The mean scores of health responsibility, nutrition, interpersonal relationships and stress management of adolescents who had game addiction were significantly lower than the adolescents without game addiction. Digital game addiction rates were significantly higher in boys, vocational high school students, ninth grade students, and in those who described that their family had low income, that they had very poor relations with their families/friends, that they had very poor living conditions and that they were generally unhappy.

Conclusions: It was determined that game addiction negatively affected adolescents' lifestyle behaviors, and there was a negative, low to moderately significant correlation between interpersonal relationships and stress management and game addiction.
\end{abstract}

Keywords: Digital game addiction, lifestyle behaviors, adolescents

\section{INTRODUCTION}

Today, computers and internet, which provide convenience in many areas of life, are also frequently used for games and entertainment in adolescents. Some aspects of digital games such as providing communication, realizing the dreams that people cannot realize in real life, experiencing a sense of winning and success make games more attractive for adolescents (1). Also, adolescents find it easier to engage with others in an imaginary world of games than face-toface communication, and they want to gain respect and reputation among other players, driving them to prefer digital games. Thus, adolescents fulfill their needs to realize themselves using digital games (2).

It has been reported that playing digital games is normal unless it is done in excess, and that games even have positive effects such as emotional relief/relaxation and improved leisure time utilization and problem-solving skills $(3,4)$. However, excessive and uncontrolled gaming has created the term game addiction and the resulting problems have caused serious concerns all over the world (5). Lemmens et al. (6) defined Digital Game Addiction (DGA) as "excessive and compulsive use of computer or video games and the player's inability to control excessive use, even though it causes social and/or emotional problems."

In the literature, game addiction is also referred to as "Game Disorder", "Online Game Addiction" and "Online Gaming Disorder". Although the definitions may differ, they basically describe gaming and the accompanying problems. In addition, it was stated that "Internet Addiction" could be related to game addiction (7). It is also noteworthy that in the third research supplement of the Diagnostic and Statistical Manual of Mental Disorders-5 (DSM-5) developed by the American Psychiatric Association, game addiction was listed under the title of personality disorders and addressed to as "recommended for further research" (8).

All individuals who play games may experience addiction as a part of the normal process. However, as a result of 
developmental changes in the brain and intense emotional and social stress during adolescence, adolescents are more vulnerable in behavior control and susceptible to addiction (5). Research has shown that male adolescents aged 10-19 are at a higher risk of game addiction than other age groups and girls $(9,10)$.

Many studies have shown that DGA was associated with many negative lifestyle behaviors such as unhealthy nutrition behaviors, sedentary life, problems in interpersonal relationships, sleep problems, low life satisfaction, avoiding responsibilities and ineffective coping with stress (11-15). In addition, it has been reported to cause a variety of psychiatric disorders including attention deficit, hyperactivity, impulse control disorders, high levels of anxiety, depression, violence tendency and suicidal ideation (16-19).

In the international prevalence studies conducted on online game addiction, it has been found that game addiction ranged from $0.3 \%$ to $50 \%(10,14,20-22)$. Especially in China, Korea and Taiwan, problematic online gaming behaviors have been reported to become a serious public health problem $(10,22)$. The establishment of specialized treatment centers in Southeast Asia, the United States and Europe reflects the seriousness of the situation (10).

Although there are no prevalence indicators at the national level in Turkey, Irmak and Erdoğan (23) found the ratio of addicted players as $28.8 \%$, Baysak et al. (24) as $11.1 \%$ and Göldağ (25) as $22.6 \%$ in their studies.

Physical inactivity, unhealthy diet, stress, cigarettealcohol-substance addiction, digital addictions, not taking responsibility for health, and negative interpersonal relationships are the biggest threats to adolescents' health. These behaviors have important lifelong consequences (2628). All kinds of addictions and game addiction constitute a risk for healthy lifestyle behaviors. The fact that adolescents who spend most of their time with playing games inactively avoid all kinds of responsibilities can also lead to avoiding health responsibilities and adopting negative behaviors (29).

Although research on digital game addiction is rapidly increasing, there is limited research examining digital game addiction and lifestyle behaviors together in adolescents who are at greater risk than others in terms of engaging in risky behaviors and developing addiction (10). In order to determine the current situation; there is a need for descriptive studies with valid and reliable measurement tools. The aim of this study is to determine digital game addiction and lifestyle behaviors in adolescents.

In this research, the answers to the following questions were sought:

- What are the digital game addiction rates of adolescents?

- What are the total scores and subscale scores of adolescents from the Game Addiction Scale for Adolescents (GASA) and Adolescent Lifestyle Profile Scale (ALPS)?
- Is there any difference between ALPS subscale scores of adolescents with and without digital game addiction?

- What are the socio-demographic characteristics of adolescents that increase the risk of game addiction?

- Is there a difference between the socio-demographic characteristics of adolescents and game addiction?

\section{METHODS}

\subsection{Population and Sample}

The population of the study consists of students from three high schools offering different types of education in Maltepe district between March and April 2017. These high schools are vocational technical high schools $(n=1954)$, an anatolian high school $(n=1317)$ and a health high school $(n=350)$ attended by a total of 3621 adolescents. In the study; sample selection was not made, it was aimed to reach the whole population. The study was completed with 2001 students (55.2\% of the population), who were at the school on the data collection days and completed the data collection forms completely. The inclusion criteria of the study were lack of communication barriers, volunteering, obtaining parental consent and completing the data collection forms completely.

\subsection{Variables}

Dependent variables: The mean scores obtained from the health responsibility, physical activity, nutrition, interpersonal relationships and stress management subscales of the ALPS were the dependent variables of the study.

Independent variables: Digital game addiction and sociodemographic characteristics including age, gender, height, weight, parents' educational level and profession, socioeconomic level, whether the adolescent worked outside the school, etc. and family relationships, friend relationships, life satisfaction, tendency to violence, coping with stress and mood were independent variables of the study.

\subsection{Data Collection Tools}

Data were collected by using the Introductory Information Form, Game Addiction Scale for Adolescents (GASA) and Adolescent Lifestyle Profile Scale (ALPS).

Introductory information form: Developed by the researchers based on the relevant literature, the form consists of 31 closed-ended questions covering school characteristics, familial characteristics, interpersonal relationships, disease and health perception, and Body Mass Index (BMI) measurements of adolescents $(28,30,31)$.

Body mass index (BMI): BMI was calculated by measuring the height and weight of the students and dividing the weight in kilograms to square meters $\left(\mathrm{kg} / \mathrm{m}^{2}\right)$. In this study, using the BMI percentile curves of Turkish children developed 
by Neyzi et al. (32), those with percentile below $5 \%$ were defined as "underweight", 5-85 percentile as "normal", between 85-95 percentile as "overweight" and above 95 percentile as "obese".

Game addiction scale for adolescents (GASA): GASA was developed by Lemmens, Valkenburg and Peter (6) to determine problematic game behaviors of adolescents between the ages of 12-18 years. The adaptation to Turkish language and validity and reliability study was conducted by llgaz (32). The Cronbach's Alpha value for the total reliability coefficient of the adapted scale was found to be 0.92 , and in this study, it was 0.94. The Cronbach's Alpha value for the subscales of the adapted scale was found to be between 0.62 0.85 , and it was between 0.70 and 0.87 in this study. The scale consists of seven subscales, namely: salience ${ }_{(1)}$, tolerance ${ }_{(2)}{ }^{\prime}$ mood modification ${ }_{(3)}$, withdrawal ${ }_{(4)}$, relapse $_{(5)}$, conflict ${ }_{(6)}$ and problems ${ }_{(7)}$. The scale is a 5-point Likert-type (1-Never, 2 - Rarely, 3 - Sometimes, 4 - Frequently, 5 - Very often). The highest score to be taken from the scale is 105 and the lowest score is 21. Higher scores indicate greater game addiction. As described by Charlton and Danforth (33) and Baysak et al. (24) monothetic vs polythetic diagnoses are used to determine game addiction. In this study, monothetic diagnosis was used for digital game addiction. According to the monothetic diagnosis, if the person scores 3 (sometimes) and above 3 in 21 items, he / she is considered addicted. In polythetic diagnosis, if he scores 3 (sometimes) and above 3 for at least 12 items, he / she is defined as a game addict. Those who scored 63 points and above from the GASA in monothetic diagnosis were digital game addicts.

Adolescent lifestyle profile scale (ALPS): The Adolescent Lifestyle Profile is a version of Health Promotion Lifestyle Profile II developed for adolescents based on the Health Promotion Model. The reliability and validity study of the scale was conducted by Hendricks, Murdaugh and Pender (34). Adaptation to the Turkish language and validity and reliability study of the scale was conducted by Ardıç (35) and Cronbach's Alpha coefficients were found to be 0.87 for the total scale and 0.58 to 0.77 of the subscales. The scale has seven subscales that can be used independently of each other. There is no cut-off point in the scale consisting of 40 items of four-point likert type. Higher scores indicate improved positive health behavior (35). The subscales are health responsibility, physical activity, nutrition, positive life perspective, stress management and spiritual health. Five subscales were used in this study, excluding the positive life perspective and spiritual health subscales. The Cronbach's Alpha coefficients of the five subscales used in this study ranged from 0.50 to 0.81 .

\subsection{Data Collection}

The data was collected between March and April 2017 by visiting the schools two days a week and using a questionnaire based on self-reporting which lasted 25 minutes on average. The questionnaires were given during the lessons when the students could complete them. Before collecting data from the population, a pilot study was conducted with a different group of 15 students to test the comprehensibility of the data collection forms.

\subsection{Statistical Analysis}

Data were evaluated in computer environment. Descriptive data were shown with numbers, percentages and means. The relationship between GASA game addiction and independent variables was evaluated by chi-square test, Mann-Whitney $U$ test, Pearson Correlation Analysis and Logistic Regression Analysis. Statistical significance was set at $p<0.05$.

\subsection{Ethical considerations}

Written permission was obtained from the Istanbul Provincial Directorate of National Education, the school administration to conduct the research. At the same time, written consent was obtained from the students and their parents to participate in the study. In order to use the GASA and ALPS in this study, permission was obtained by e-mail from the authors who adapted the Turkish version. Ethical permission was obtained from the Ethics Committee of the Institute of Health Sciences (09.10.2017-193) of a university.

\section{RESULTS}

The mean age of the study sample was $16.5 \pm 1.0$ years $(\min =14, \max =19) .58 .1 \%$ of the adolescents were between $14-16$ years, $4.9 \%$ of them were between $17-19$ years of age. $33.4 \%$ of the adolescents were girls, $56.2 \%$ were vocational technical high school students and $31 \%$ were studying in 10th grade, and $57.5 \%$ had $1-2$ siblings. The mean body weight of the students was $63.27 \pm 12.7 \mathrm{~kg}$, average height was 171.43 $\pm 16.4 \mathrm{~cm}$, mean BMI was $21.48 \pm 3.42$ and $5.6 \%$ of them were obese according to their percentiles. The average monthly income of $29.5 \%$ of the families was between 1501 2500 TL (Table 1).

Adolescents scored $48.64 \pm 19.83$ points on average on the Game Addiction Scale. The highest score (mean=8.46 \pm 3.77) from the subscales was from the mood modification subscale, while the lowest score was from the problems subscale (mean=5.97 \pm 3.07 ). The highest score from the subscales of the Adolescent Lifestyle Profile Scale was from the interpersonal relationships subscale (mean $=14.98 \pm 3.39$ ) while and the lowest score was from the health responsibility subscale (mean $=10.50 \pm 2.38$ ) (Table 2 ).

The scores of adolescents from the ALPS subscales were compared by whether the adolescent had game addiction and the results are provided in Table 3. Accordingly, there was a significant difference between game addiction and health responsibility $(Z=3.416 ; p=.001)$, nutrition $(Z=2.071$; $p=.038)$, interpersonal relationships $(Z=4.585 ; p=.000)$ and stress management $(Z=3.936 ; p=.000)$ subscales. The mean scores of the adolescents with game addiction were lower (Table 3). 
$22.4 \%$ of the adolescents $(n=449)$ were considered to have game addiction with a score of 63 or higher from GASA. The addiction ratios of the adolescents were compared with independent variables and the results are shown in Table 2. Boys $\left(\chi^{2}=64.89 ; p=.000\right)$, vocational high school students $(\chi$ $\left.{ }^{2}=20.82 ; p=.000\right)$, ninth grade students $\left(\chi^{2}=13.13 ; p=.004\right)$, those with the lowest family income $\left(\chi^{2}=16.32 ; p=.003\right)$, those who described that they had very poor relations with their families ( $\left.\chi^{2}=32.42 ; p=.000\right)$ and friends $\left(\chi^{2}=12.99\right.$; $p=.005)$ and those who described that they had very poor living conditions $\left(\chi^{2}=17.80 ; p=.000\right)$ had higher addiction rates than the others (Table 4 ).

Table 1. Socio-demographic characteristics of adolescents who participated in the study $(n=2001)$

\begin{tabular}{|c|c|c|c|}
\hline \multicolumn{2}{|l|}{ Variables } & \multicolumn{2}{|c|}{ Mean (SD) } \\
\hline \multicolumn{2}{|l|}{ Age (mean $\pm S D)$} & \multicolumn{2}{|c|}{$16.5 \pm 1.07$ years } \\
\hline \multirow{3}{*}{ Age groups } & & $\mathrm{n}$ & $\%$ \\
\hline & 14-16 age & 1163 & 58.1 \\
\hline & 17-19 age & 838 & 41.9 \\
\hline \multirow[t]{3}{*}{ Gender } & Female & 668 & 33.4 \\
\hline & Male & 1333 & 66.6 \\
\hline & Technical High School & 1124 & 56.2 \\
\hline \multirow[t]{3}{*}{ School type } & Health High School & 207 & 10.3 \\
\hline & Anatolian High School & 670 & 33.5 \\
\hline & Grade 9 & 531 & 26.5 \\
\hline \multirow{3}{*}{ Grade } & Grade 10 & 620 & 31.0 \\
\hline & Grade 11 & 613 & 30.7 \\
\hline & Grade 12 & 237 & 11.8 \\
\hline \multirow{4}{*}{ Number of Siblings } & 1-2 siblings & 1150 & 57.5 \\
\hline & 3 -siblings & 462 & 23.1 \\
\hline & 4 and over & 247 & 12.3 \\
\hline & None & 142 & 7.1 \\
\hline \multirow{4}{*}{ BMI Percentiles } & $\begin{array}{l}\text { Under weight } \\
\text { (<5. Perc.) }\end{array}$ & 301 & 15.1 \\
\hline & Normal (5-85 Perc.) & 1443 & 72.1 \\
\hline & $\begin{array}{l}\text { Overweight } \quad \text { (85 } \\
95 \text { perc.) }\end{array}$ & 144 & 7.2 \\
\hline & Obese (>95 perc.) & 112 & 5.6 \\
\hline \multirow{5}{*}{ Family Income } & $500-1000 \mathrm{TL}$ & 83 & 4.2 \\
\hline & $1001-1500 \mathrm{TL}$ & 345 & 17.2 \\
\hline & $1501-2500 \mathrm{TL}$ & 590 & 29.5 \\
\hline & $2501-3500 \mathrm{TL}$ & 467 & 23.3 \\
\hline & 3501 and over & 516 & 25.8 \\
\hline
\end{tabular}

$S D=$ Standard Deviation, $B M I=$ Body Mass Index
A moderately negative statistically significant correlation was found between the Problems sub-dimension of GASA and the stress management sub-dimension of ALPS ( $r=-.520$; $\mathrm{p}=.000$ ). Either there was no correlation, or a very low level of significant correlation was found between the other subdimensions of the two scales (Table 5).

When independent variables associated with game dependence were subjected to logistic regression analysis, it was found that the risk of developing game addiction was 2.75 times higher for male adolescents than female adolescents, 0.76 times higher for 12 th grade students, 0.82 times higher for those with a family income of 500-1000 TL and below, 1.48 times higher for those who described that they had very poor relations with the family, 1.34 times higher for those who described that they had very poor relations with the friends, 0.78 times higher for those who experienced sleep problems, 0.62 times higher for those who resort to violence, 1.58 times higher for those who do not have a healthy lifestyle, and 0.50 times higher for those who played digital games $(p<0.05)$ (Table 6).

Table 2. Distribution of total and sub-dimension mean scores of Game Addiction Scale for Adolescents and Adolescent Lifestyle Profile Scale

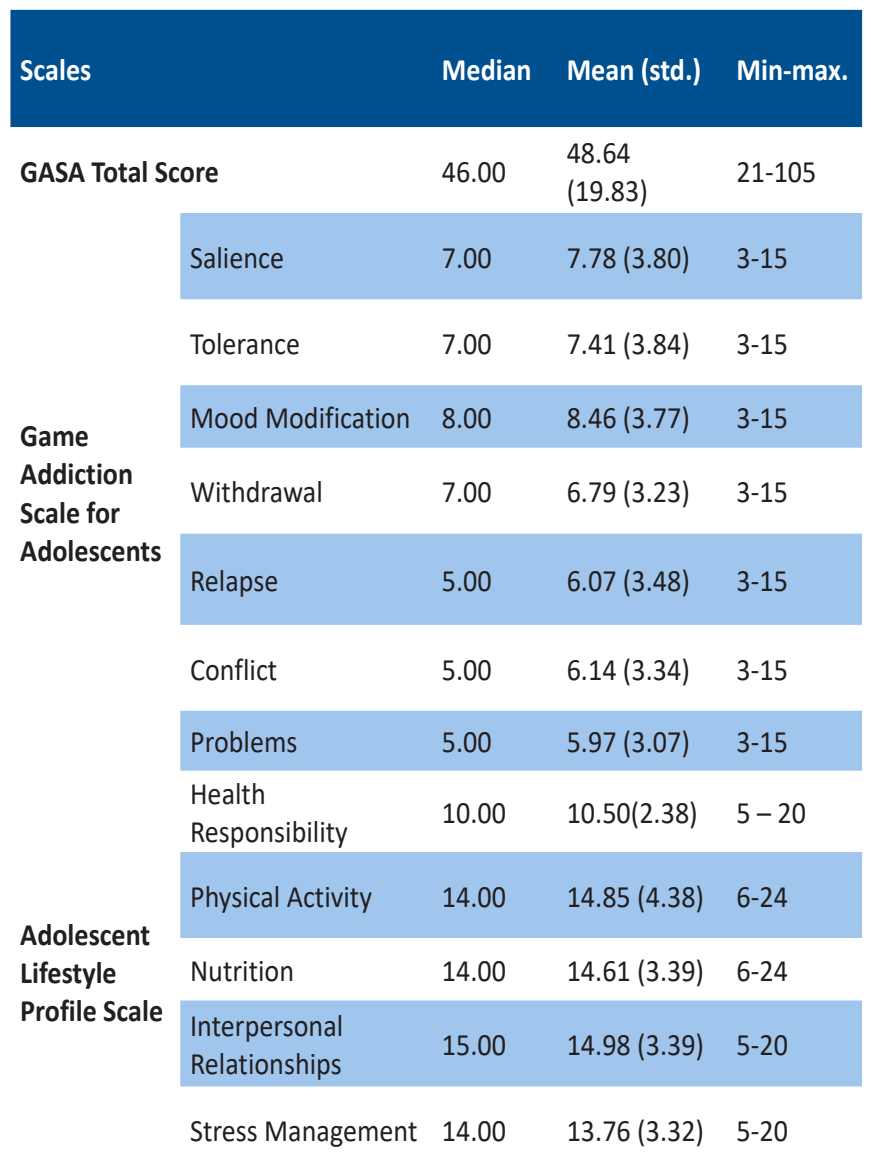

GASA: Game Addiction Scale for Adolescents 
Table 3. Distribution of the mean scores of the subscale scores of adolescents with and without game addiction

\begin{tabular}{|c|c|c|c|c|c|c|c|c|}
\hline \multirow{3}{*}{$\begin{array}{l}\text { Sub } \\
\text { dimensions } \\
\text { of } \\
\text { ALPS }\end{array}$} & \multicolumn{6}{|l|}{ GASA } & \multirow{2}{*}{\multicolumn{2}{|c|}{ Statistics }} \\
\hline & \multicolumn{3}{|c|}{ GASA Not Addicted ( $n=1552$ ) } & \multicolumn{3}{|c|}{ GASA Addicted ( $n=449)$} & & \\
\hline & Median & $\begin{array}{l}25 .-75 . \\
\text { quarter }\end{array}$ & Mean (std.) & Median & $\begin{array}{l}25 .-75 . \\
\text { quarter }\end{array}$ & Mean. (std.) & Z & $\mathbf{P}$ \\
\hline Health Responsibility & 10.00 & $9-12$ & $10.58(2.32)$ & 10.00 & 8-12 & $10.22(2.54)$ & 3.416 & .001 \\
\hline Physical Activity & 15.00 & $12-18$ & $14.93(4.31)$ & 14.00 & $11-18$ & $14.57(4.60)$ & 1.434 & .151 \\
\hline Nutrition & 14.00 & $12-17$ & $14.70(3.33)$ & 14.00 & $12-17$ & $14.28(3.59)$ & 2.071 & .038 \\
\hline Interpersonal Relationships & 15.00 & $13-18$ & $15.19(3.22)$ & 14.00 & $12-17$ & $14.25(3.68)$ & 4.585 & .000 \\
\hline Stress Management & 14.00 & $12-16$ & $13.89(3.31)$ & 13.00 & $11-16$ & $13.18(3.33)$ & 3.936 & .000 \\
\hline
\end{tabular}

$Z=$ Mann-Whitney $U$ test

ALPS: Adolescent Lifestyle Profile Scale; GASA: Game Addiction Scale for Adolescents

Table 4. Comparison of socio-demographic characteristics and game addiction of adolescents

\begin{tabular}{|c|c|c|c|c|c|c|c|}
\hline & & Accorc & ASA Mon & ic form & & & \\
\hline Variables & & Not $A c$ & $(n=1552)$ & Addic & 449) & Statisti & \\
\hline & & n & $\%$ & $\mathbf{n}$ & $\%$ & $x^{2}$ & p \\
\hline Gender & Female & 589 & 88.2 & 79 & 11.8 & 6489 & 00 \\
\hline Genaer & Male & 963 & 72.2 & 370 & 27.8 & 04.09 & .00 \\
\hline & Technical High School & 832 & 74.0 & 292 & 26.0 & & \\
\hline School Type & Health High School & 178 & 86.0 & 29 & 14.0 & 20.82 & .00 \\
\hline & Anatolian High School & 542 & 80.9 & 128 & 19.1 & & \\
\hline & Grade 9 & 387 & 72.9 & 144 & 27.1 & & \\
\hline Grade & Grade 10 & 486 & 78.4 & 134 & 21.6 & 13.13 & .00 \\
\hline & Grade 11 & 500 & 81.6 & 113 & 18.4 & 20.20 & \\
\hline & Grade 12 & 179 & 75.5 & 58 & 24.5 & & \\
\hline & $500-1000 \mathrm{TL}$ & 59 & 71.1 & 24 & 28.9 & & \\
\hline & $1001-1500 \mathrm{TL}$ & 270 & 78.3 & 75 & 21.7 & & \\
\hline Family Income & $1501-2500 \mathrm{TL}$ & 462 & 78.3 & 128 & 21.7 & 16.32 & .00 \\
\hline & $2501-3500 \mathrm{TL}$ & 386 & 82.7 & 81 & 17.3 & & \\
\hline & 3501 and over & 375 & 72.7 & 141 & 27.3 & & \\
\hline & Very good & 778 & 82.7 & 163 & 17.3 & & \\
\hline Familv Rolatisnshins & Good & 698 & 74.1 & 244 & 25.9 & & \\
\hline ramily Relationsnips & Bad & 59 & 64.8 & 32 & 35.2 & 32.42 & .00 \\
\hline & Very Bad & 17 & 63.0 & 10 & 37.0 & & \\
\hline & Very good & 735 & 78.8 & 198 & 21.2 & & \\
\hline Friend & Good & 756 & 77.9 & 215 & 22.1 & 1299 & 00 \\
\hline Relationships & Bad & 41 & 64.1 & 23 & 35.9 & 26.00 & .0 \\
\hline & Very Bad & 20 & 60.6 & 13 & 39.4 & & \\
\hline & Very good & 426 & 80.2 & 105 & 19.8 & & \\
\hline Living conditions & Good & 1018 & 78.1 & 286 & 21.9 & 17.80 & .00 \\
\hline & Bad & 90 & 66.2 & 46 & 33.8 & & \\
\hline & Very Bad & 18 & 60.0 & 12 & 40.0 & & \\
\hline & Yes & 754 & 80.6 & 181 & 19.4 & & \\
\hline happy? & No & 240 & 69.8 & 104 & 30.2 & 17.13 & .00 \\
\hline & Sometimes & 558 & 77.3 & 167 & 22.7 & & \\
\hline
\end{tabular}

$\chi^{2=}$ Pearson Chi-Square; GASA: Game Addiction Scale for Adolescents; TL: Turkish Lira 
Table 5. Correlation between subdimensions of Game Addiction Scale for Adolescents and Adolescent Lifestyle Profile Scale

\begin{tabular}{|c|c|c|c|c|c|}
\hline \multirow{3}{*}{$\begin{array}{l}\text { GASA } \\
\text { Subdimensions }\end{array}$} & \multicolumn{5}{|c|}{ ALPS Subdimensions } \\
\hline & $\begin{array}{l}\text { Health } \\
\text { Responsibility }\end{array}$ & Physical Activity & Nutrition & $\begin{array}{l}\text { Interpersonal } \\
\text { Relationships }\end{array}$ & Stress Management \\
\hline & $r(p)$ & $r(p)$ & $r(p)$ & $r(p)$ & $r(p)$ \\
\hline Salience & $-.022(.320)$ & $.016(.477)$ & $.003(.883)$ & $-.120(.000)$ & $-.033(.136)$ \\
\hline Tolerence & $-.026(.247)$ & $.009(.673)$ & $.007(.749)$ & $-.154(.000)$ & $-.078(.000)$ \\
\hline Mood Modification & $-.016(.473)$ & $.025(.268)$ & $-.003(.898)$ & $-.049(.029)$ & $-.032(.151)$ \\
\hline Withdrawal & $-.020(.364)$ & $-.030(.123)$ & $-.029(.193)$ & $-.129(.000)$ & $-.107(.000)$ \\
\hline Relapse & $-.031(.161)$ & $-.013(.563)$ & $-.034(.125)$ & $-.174(.000)$ & $-.115(.000)$ \\
\hline Conflict & $-.052(.020)$ & $-.028(.213)$ & $-.035(.122)$ & $-.162(.000)$ & $-.132(.000)$ \\
\hline Problems & $-.041(.065)$ & $-.005(.814)$ & $-.026(.239)$ & $-.139(.000)$ & $-.520(.000)$ \\
\hline
\end{tabular}

Table 6. Logistic regression analysis of independent variables with game addiction

\begin{tabular}{|c|c|c|c|c|c|}
\hline Variables & & B & $\operatorname{Exp}(B)$ & Sig. & $95 \% \mathrm{Cl}$ \\
\hline Gender & $\begin{array}{l}\text { Female } \\
\text { Male }\end{array}$ & 1.01 & 2.75 & 0.00 & $\begin{array}{l}2.00- \\
3.79\end{array}$ \\
\hline School type & $\begin{array}{l}\text { Anatolian High } \\
\text { School } \\
\text { Health High } \\
\text { School } \\
\text { Technical High } \\
\text { School }\end{array}$ & 0.14 & 1.15 & 0.33 & $\begin{array}{l}0.87- \\
1.56\end{array}$ \\
\hline Grade & $\begin{array}{l}\text { Grade } 9 \\
\text { Grade } 10 \\
\text { Grade } 11 \\
\text { Grade } 12\end{array}$ & 0.27 & 0.76 & 0.02 & $\begin{array}{l}0.51- \\
1.12\end{array}$ \\
\hline Family income & $\begin{array}{l}500-1000 \mathrm{TL} \\
1001-1500 \mathrm{TL} \\
1501-2500 \mathrm{TL} \\
2501-3500 \mathrm{TL} \\
3501 \mathrm{TL} \text { and over }\end{array}$ & 0.18 & 0.82 & 0.00 & $\begin{array}{l}0.45- \\
1.49\end{array}$ \\
\hline $\begin{array}{l}\text { Family } \\
\text { relationships }\end{array}$ & $\begin{array}{l}\text { Very Good } \\
\text { Good } \\
\text { Bad } \\
\text { Very Bad }\end{array}$ & 0.39 & 1.48 & 0.01 & $\begin{array}{l}0.58- \\
3.79\end{array}$ \\
\hline $\begin{array}{l}\text { Friend } \\
\text { relationships; }\end{array}$ & $\begin{array}{l}\text { Very Good } \\
\text { Good } \\
\text { Bad } \\
\text { Very Bad }\end{array}$ & 0.28 & 1.34 & 0.03 & $\begin{array}{l}0.55- \\
3.28\end{array}$ \\
\hline Sleep problems & $\begin{array}{l}\text { No } \\
\text { Yes }\end{array}$ & 0.24 & 0.78 & 0.04 & $\begin{array}{l}0.57- \\
1.06\end{array}$ \\
\hline Enjoying life & $\begin{array}{l}\text { Yes } \\
\text { Sometimes } \\
\text { No }\end{array}$ & 0.14 & 1.15 & 0.47 & $\begin{array}{l}0.78- \\
1.69\end{array}$ \\
\hline Healthy Lifestyle & $\begin{array}{l}\text { No } \\
\text { Yes }\end{array}$ & 0.45 & 1.58 & 0.00 & $\begin{array}{l}1.22- \\
2.04\end{array}$ \\
\hline $\begin{array}{l}\text { Resort to } \\
\text { violence }\end{array}$ & $\begin{array}{l}\text { No } \\
\text { Yes }\end{array}$ & 0.47 & 0.62 & 0.00 & $\begin{array}{l}0.45- \\
0.86\end{array}$ \\
\hline $\begin{array}{l}\text { Playing digital } \\
\text { games in free } \\
\text { time }\end{array}$ & $\begin{array}{l}\text { No } \\
\text { Yes }\end{array}$ & 0.68 & 0.50 & 0.00 & $\begin{array}{l}0.39- \\
0.64\end{array}$ \\
\hline
\end{tabular}

\section{DISCUSSION}

In this study, which was conducted to determine the digital game addiction and lifestyle behaviors of adolescents, it was found that approximately one fourth of the adolescents were addicted to digital games. Among the sub-scales of GASA, the highest score was obtained from the mood changing subscale, and the lowest score was obtained from the problems subscale. Adolescents got the highest score from the interpersonal relationships subscale, and the lowest score from the health responsibility subscale from the ALPS. Game addicted adolescents; average scores for health responsibility, nutrition, interpersonal relationships, and stress management were lower than non-game addicts. Digital game addiction rates of males, vocational high school students, ninth grade students, those with low family income, those who stated that their relations with their family and friends were very weak, and those who stated that they were generally unhappy were found to be higher than the others.

In this study, it was found that adolescents who are addicted to digital games assume less health responsibility than adolescents who are not addicted to digital games. It is stated in the literature that adolescents who spend most of their time with playing games may inactively avoid all kinds of responsibilities including health responsibility and adopt negative behaviors (29). In their research, Stockdale and Coyne (36) found that individuals with game addiction had poorer health than those without game addiction.

In this study, it was determined that adolescents with digital game addiction ate unhealthy food. The mean score of the adolescents with game addiction was lower. In parallel with our study findings, there are studies showing that problematic gaming and technology-related addictions are associated with poor nutrition habits $(11,37)$. In this study, it was determined that game addicted adolescents got lower scores in ALPS interpersonal relations dimension. It has been reported that excessive game play isolates people and decreases their level of socialization (27). It was reported that symptoms of problematic gaming and social media use 
negatively affects adolescents' life satisfaction, and that symptoms of problematic gaming had a negative effect on their perceived social competence (38).

In this study, adolescents with game addiction had lower scores from the stress management subscale of ALPS than those without game addiction. Saquib et al. (39) found a strong and significant correlation between game addiction and stress and stated that individuals with game addiction were at 4.7 times higher risk than those without game addiction. Mentzoni et al. (14) found that people with psychological health problems were more prone to game addiction. There are studies showing that adolescents use online games as a tool to deal with stress $(21,37)$. The results showing that games provide emotional relief and relaxation also support this finding (3). These findings suggest that adolescents play digital games to cope with stress or that their stress increases as they play.

This research found that $27.8 \%$ of male adolescents and $11.8 \%$ of female adolescents were addicted to digital games. In addition, according to logistic regression analysis, it was found that males had a 2.75 times higher risk of being dependent. This finding is in line with the findings of previous studies $(14,37)$. In the study of Wittek et al. $(40)$, it was found that males were 2.9 times more likely to have game addiction than females. In a study, higher activity and functional link was found in the mesocorticolimbic system that controls brain pleasure mechanisms and behaviors in male compared to female subjects with game addiction (41). However, the addictive potential of the game types preferred by men may be higher. It is also thought that this finding may be due to the fact that most of the games are prepared by men for men (19).

In this study, it was seen that $28.9 \%$ of those with low family income were high and $27.3 \%$ of those with high family income had digital game addiction and their addiction rates were higher than other income groups. In addition, analysis has shown that having a low income increases the risk of game addiction. In the literature, it is stated that families with low income have lower education level. Families with low levels of education may not know the negative effects of game addiction and strategies to protect adolescents from game addiction (42). On the other hand, it is stated in the literature that adolescents with high income level play more online games to spend time and for social interaction. It is also mentioned that children of families with higher incomes can easily access digital gaming means, which may increase game addiction (25). The high level of addiction of adolescents in both low and high income families suggested that game addiction was not only affected by family income. Therefore, awareness of parents and adolescents should be raised regarding game addiction in both settings.

Adolescents with poor family and friends relationships were found to have a higher risk of game addiction. The results of the study by Choi et al. (43) showed that adolescents play online games to spend time and engage in social interaction. Lenhart (44) in his study; reported that $72 \%$ of teens play online games every day and that these teens have poor friendships in daily life. In the study of Bonnaire and Phan (45), adolescents who have poor family relationships and conflict with their families experienced problematic gaming and online gaming disorders significantly more than others. In addition, Han et al. (46) reported in their study that harmony within the family may be important in controlling problematic gaming. In line with these findings, it can be concluded that both poor family and friend relationships lead adolescents to game addiction and that game addiction affects family and friend relationships negatively.

In this study, digital game addiction was found to be higher in adolescents with sleep problems. It has been reported that in adolescence, 7.5 hours of sleep for girls and 8.5 hours for boys are necessary for a healthy life (28). It has been reported that game addiction disrupts normal sleep patterns of adolescents and generally causes less sleep, longer time to fall asleep and more interruptions during sleep $(13,47)$. There are studies showing that time and duration of sleep are affected by digital game addiction $(14,28,39)$. Results of other studies also show that game addiction is associated with sleep problems $(10,48)$.

\section{CONCLUSIONS}

The results showed that game addiction negatively affects healthy lifestyle of adolescents. It should be noted that male gender, vocational high school students, adolescents with low family income and those with poor relationships with family/friend constitutes risky groups. The inclusion of efforts to improve stress management, family and friendship relations and to develop communication skills and good nutrition, sleep, and healthy lifestyle behaviors to prevent and reduce game addiction can increase the effectiveness of the initiatives.

\section{Conflict of Interest}

There are no conflicts of interest in connection with this paper.

\section{REFERENCES}

[1] Ögel K. İnternet bağımlılığı, internetin psikolojisini anlamak ve bağımlııkla başa çıkmak. Türkiye İş Bankası Kültür Yayınları; 2012. p.47-60.

[2] Huanhuan L, Su W. The role of cognitive distortion in online game addiction among Chinese adolescents. Children and Young Servises Review 2013;35:1468-1475.

[3] Prot S, Anderson CA, Gentile DA, Brown SC, Swing EL. The positive and negative effects of video game play. Media and the well-being of children and adolescents 2014,109: 20102014.

[4] Bakar A, Tüzün H, Çağıltay K. Öğrencilerin eğitsel bilgisayar oyunu kullanımına ilişkin görüşleri: Sosyal bilgiler dersi örneği. Hacettepe Üniversitesi Eğitim Fakültesi Dergisi 2008;35.35:27-37.

[5] Kojima R, Sato M, Akiyama Y, Mizorogi S, Shinohara R, Suzuki $\mathrm{K}$, et al. Problematic internet use and its associations with 
health-related symptoms and lifestyle habits among rural Japanese adolescents. Psychiatry Clin Neurosci 2019;73(1):2026.

[6] Lemmens JS, Valkenburg PM, Peter J. Development and validation of a game addiction scale for adolescents. Media Psychol 2009;12:77-95.

[7] WHO: Sharpening the focus on gaming disorder. Available at: https://www.who.int/bulletin/volumes/97/6/19-020619/en/

[8] Köroğlu E (editor). Amerikan Psikiyatri Birliği. Ruhsal Bozuklukların Tanısal ve Sayımsal El Kitabı (DSM-5). 5. Baskı. Ankara: Hekimler Yayın Birliği; 2013.

[9] Greenberg BS, Sherry J, Lachlan K, Lucas K, Holmstrom A. Orientations to video games among gender and age groups. Simulation and Gaming 2010;41(2)238-259.

[10] Kuss DJ. Internet gaming addiction: Current perspectives. Psychol Res Behav Manag 2013;6:125-37.

[11] Bener A, Al-Mahdi HS, Ali Al, Nufal MA. Obesity and low vision as a result of excessive Internet use and television viewing. Int J Food Scien Nutrition 2011;62:60-2.

[12] Mérelle SYM, Kleiboer AM, Schotanus M, Cluitmans TLM, Waardenburg CM, Kramer D, et al. Which health related problems are associated with problematic video-gaming or social media use in adolescents? A large scale cross-sectional public health study. Clinical Neuropsychiatry 2017;14(1):1119.

[13] Hale L, Guan S. Screen time and sleep among school-aged children and adolescents: A systematic literature review. Sleep Medicine Reviews 2015;21:50-58.

[14] Mentzoni RA, Brunborg GS, Molde H, Myrseth H, Skouverøe $\mathrm{KJM}$, Hetland J, et al. Problematic video game use: Estimated prevalence and associations with mental and physical health. Cyberpsychol Behav Soc Netw 2011;14:591-6.

[15] Koo HJ, Kwon JH. Risk and protective factors of Internet addiction: A meta-analysis of empirical studies in Korea. Yonsei Medical Journal 2014;55:1691-1711.

[16] Greitemeyer T, Mügge DO. Video games do affect social outcomes: A meta-analytic review of the effects of violent and prosocial video game play. Personality and Social Psychology Bulletin 2014;40(5):578-589.

[17] Hasan Y, Bègue L, Scharkow M, Bushman BJ. The more you play, the more aggressive you become: $A$ long-term experimental study of cumulative violent video game effects on hostile expectations and aggressive behavior. Journal of Experimental Social Psychology 2013;49(2):224-227.

[18] Fischer P, Kastenmüller A, Greitemeyer T. Media violence and the self: The impact of personalized gaming characters in aggressive video games on aggressive behavior. Journal of Experimental Social Psychology 2010;46(1):192-195.

[19] Grifiths MD, Andreassen SC, Billieuxs J, Kuss Dj, Demetrovics $Z$, Mazzoni E, et al. The relationship between addictive use of social media and video games and symptoms of psychiatric disorders: A large-scale cross-sectional study. Psychol Addict Behav 2016;30(2):252-62.

[20] Gentile DA, Choo H, Sim T, Khoo A, Liau A. Pathological video-gaming among Singaporean youth. Ann Acad Med 2010;39:822-9.

[21] Seok HJ, Lee JM, Park CY, Park JY. Understanding internet gaming addiction among South Korean adolescents through photo voice. Children and Youth Services Review 2018;94:35-42.

[22] Lin H, Sun CT. Cash trade in free-to-play online games. Games and Culture 2011;6(3): 270-287.
[23] Irmak AY, Erdoğan S. Dijital oyun bağımlılığı ölçeği Türkçe formunun geçerliliği ve güvenilirliği. Anadolu Psikiyatri Dergisi 2015;16:10-9.

[24] Baysak E, Kaya FD, Dalgar I, Candansayar S. Online game addiction in a sample from Turkey: Development and Validation of the Turkish Version of Game Addiction Scale. Klinik Psikofarmakoloji Bulteni 2016;26(1):21-31.

[25] Göldağ B. Lise öğrencilerinin dijital oyun bağımlılık düzeylerinin demografik özelliklerine göre incelenmesi. Yüzüncü Yıl Üniversitesi Eğitim Fakültesi Dergisi 2018;15(1)1287-1315.

[26] Rauner A, Mess F, Woll A. The relationship between physical activity, physical fitness and overweight in adolescents: A systematic review of studies published in or after 2000. BMC Pediatrics 2013;13:19.

[27] Festl R, Scharkow M, Quandt T. Problematic computer game use among adolescents, younger and older adults. Addiction 2013;108:592-599.

[28] Ojio Y, Nishida A, Schimodera S, Togo F, Sasaki T. Sleep duration associated with the lowest risk of depression/ anxiety in adolescents. Sleep 2016;39(8):1555-1562.

[29] Bayzan Ş. Bilgisayar ve Oyun bağımlılı̆ı üzerine. Available at:http://www.guvenliweb.org.tr/aileler/content/bilgisayarve-internet-oyun-bagımlılıgıuzerine.

[30] Bebis H, Özdemir Ö. Kreşlerde okul sağlığı hizmetleri ve hemşirelik/School health services and nursing in nurseries. Turkish Journal of Public Health 2015;11(3):186-186.

[31] Neyzi O, Günöz H, Furman A, Bundak R. Türk çocuklarında vücut ağırlığı, boy uzunluğu, baş çevresi ve vücut kitle indeksi referans değerleri. Çocuk Sağlığı ve Hastalıkları Dergisi 2008;51:1-14.

[32] Ilgaz H. Ergenler için oyun bağımlılığı ölçeğinin Türkçe'ye uyarlama çalışması. Elementary Education Online 2015;14(3),874-884.

[33] Charlton JP, Danforth DW. Distinguishing addiction and high engagement in the context of online game playing. Comput Hum Behav 2007;23:1531-1548.

[34] Hendricks C, Murdaugh CL, Pender N. The Adolescent Lifestyle Profile: development and psychometric characteristics. Journal of National Black Nurses' Association: JNBNA 2006;17(2),1-5.

[35] [35] Ardıc A, Esin MN. The adolescent lifestyle profile scale reliability and validity of the Turkish version of the instrument. Journal of Nursing Research 2015;23-1:33-40.

[36] Stockdale L, Coyne SM. Video game addiction in emerging adulthood: Cross sectional evidence of pathology in video game addicts as compared to matched healthy controls. Journal of Affective Disorder 2017;225:265-272.

[37] Kim Y, Park JY, Kim SB, Jung IK, Lim YS, Kim JH. The effects of Internet addiction on the lifestyle and dietary behavior of Korean adolescents. Nutrition Research and Practice 2010;4:51-57.

[38] Peeters M, Koning I, Van ER. Predicting Internet gaming disorder symptoms in young adolescents: A one-year follow-up. Computers in Human Behavior 2018;80:255-261.

[39] Saquib N, Saquib J, Wahid A, Ahmed AA, Dhuhayr HE, Zaghloul MS, et al. Video game addiction and psychological distress among expatriate adolescents in Saudi Arabia. Addict Behav Rep Sep 2017;28;6:112-117.

[40] Wittek CT, Finserås TR, Pallesen S, Mentzoni RA. Prevalence and predictors of video game addiction: A study based on 
a national representative sample of gamers. International Journal of Mental Health and Addiction 2015;14(5):672-686.

[41] Hoeft F, Watson CL, Kesler SR, Bettinger KE, Reiss AL. Gender differences in the mesocorticolimbic system during computer gameplay. Journal of Psychiatric Research 2008;42:253-258.

[42] Hwang GJ, WuPH, Chen CC, TuNT. Effects of anaugmented reality based educational game on students' learning achievements and attitudes in real-world observations. Interactive Learning Environments 2016;24(8):1895-1906.

[43] Lee J, Lee M, Choi IH. Social network games uncovered: Motivations and their attitudinal and behavioral outcomes. Cyberpsychology, Behavior and Social Networking 2012;15.12:643-648.

[44] Lenhart A. Teens, social media and technology overview 2015. Available at: http://www.pewinternet.org/2015/04/09/teenssocial-media-technology2015/
[45] Bonnaire C, Phan O. Relationships between parental attitudes, family functioning and Internet gaming disorder in adolescents attending school. Psychiatry Res 2017;255:104-110.

[46] Han DH, Kim SM, Lee YS, Renshaw PF. The effect of family therapy on the changes in the severity of online game play and brain activity in adolescents with online game addiction. Psychiatry Res 2012;202:126-131.

[47] Hysing M, Pallesen S, Stormark KM, Jakobsen R, Lundervold AJ, Sivertsen B. Sleep and use of electronic devices in adolescence: results from a large population-based study. BMJ open 2015;5.1:e006748.

[48] King DL, Gradisar M, Drummond A Lovato N, Wessel J, Micic $G$, et al. The impact of prolonged violent video gaming on adolescent sleep: An experimental study. J Sleep Res 2013;2:137-43.

How to cite this article: Aksoy Z, Erol S. Digital Game Addiction and Lifestyle Behaviors in Turkish Adolescents. Clin Exp Health Sci 2021; 11: 589-597. DOI: 10.33808/clinexphealthsci.885988 